\title{
The Mere Mention of Asians in Affirmative Action
}

\author{
Jennifer Lee, ${ }^{a} \operatorname{Van}$ C. $\operatorname{Tran}^{\mathrm{b}}$
}

a) Columbia University; b) CUNY

Abstract: Presumed competent, U.S. Asians evince exceptional educational outcomes but lack the cultural pedigree of elite whites that safeguard them from bias in the labor market. In spite of their nonwhite minority status, Asians also lack the legacy of disadvantage of blacks that make them eligible beneficiaries of affirmative action. Their labor market disadvantage coupled with their exclusion from affirmative action programs place Asians in a unique bind: do they support policies that give preferences to blacks but exclude them? Given their self- and group interests, this bind should make Asians unlikely to do so. We assess whether this is the case by comparing their attitudes to those of whites, blacks, and Hispanics. Drawing on a novel three-way framing experiment embedded in the 2016 National Asian American Survey, we document how the "mere mention of Asians" in affirmative action frames affects support for the preferential hiring and promotion of blacks. Support shifts in different ways among all groups depending on the mere mention of Asians as either victims of affirmative action alongside whites or as victims of discrimination alongside blacks. Moreover, among Asians, support for affirmative action differs significantly by immigrant generation: first-generation Asians express the weakest support.

Keywords: Asian Americans; affirmative action; racial attitudes; group position; group threat; framing experiment

Citation: Lee, Jennifer, and Van C. Tran. 2019. "The Mere Mention of Asians in Affirmative Action." Sociological Science 6: 551-579.

Received: July 15, 2019

Accepted: September 2, 2019

Published: September 26, 2019

Editor(s): Jesper Sørensen, Kim Weeden

D0I: $10.15195 / \mathrm{v} 6 . \mathrm{a} 21$

Copyright: (C) 2019 The Author(s). This open-access article has been published under a Creative Commons Attribution License, which allows unrestricted use, distribution and reproduction, in any form, as long as the original author and source have been credited. (C) (i)
A SIANS account for 6.7 percent of the U.S. population yet comprise about 25 percent of the student body at Ivy League universities, including Harvard, which is currently facing a lawsuit for allegedly discriminating against Asian applicants. ${ }^{1}$ In spite of the allegation, Asians are overrepresented in elite universities and graduate from college at significantly higher rates than all U.S. groups (Hsin and Xie 2014; Jiménez and Horowitz 2013; Lee and Zhou 2015). Their educational advantage, however, disappears in the labor market. Despite being more likely to graduate from college than whites, Asians are neither more likely to attain a professional job nor earn as much as comparably educated whites, even after adjusting for age, gender, nativity, education, college selectivity, academic major, employment sector, and region of the country (Alba and Barbosa 2016; Kim and Sakamoto 2010; Kim and Zhao 2014; Tran, Lee, and Huang 2019). They are also the least likely racial group to be promoted to managerial and executive ranks even in fields in which Asians are overrepresented as professionals such as technology and law (Chung et al. 2017; Gee and Peck 2017). That their educational advantage fails to transfer to the labor market has led researchers to posit that Asians face a "bamboo ceiling" - an invisible barrier to advancement akin to the "glass ceiling" that women face (Gee, Peck, and Wong 2015).

Claims of bias against Asian applicants in university admissions have captivated the nation and placed affirmative action on trial, yet reports of bias against Asians in the workplace have received scant attention. The lack of attention is, in part, the 
result of the prevailing narrative that Asians are a high-achieving minority who excel in spite of their socioeconomic background and nonwhite racial status ( $\mathrm{Wu}$ 2015). The inattention is also the result of Asians' unique group position: in spite of their nonwhite status and labor disadvantage vis-à-vis whites, Asians lack the legacy of discrimination of blacks that affords them the status of a disadvantaged minority who is eligible for affirmative action in the workplace. Their group position places Asians in a unique bind: do they support policies that give preferences to blacks but exclude them?

Although researchers have examined Asians' attitudes of affirmative action in higher education (Wong, Lee, and Tran 2018), none have studied their opinion of racial preferences in the labor market. We shift the analytical lens and study Asians' attitudes of affirmative action in the workplace-a domain in which exceptional educational credentials do not safeguard Asians from stalled occupational mobility (Alba and Barbosa 2016; Huang 2019; Tran et al. 2019) and where affirmative action could help them break though the bamboo ceiling.

At the core of how Asians respond to the bind is whether they perceive themselves as victims of affirmative action alongside whites or victims of discrimination alongside blacks. Until recently, the field lacked nationally representative survey data to examine this question (Moberg, Krysan, and Christianson forthcoming). The 2016 National Asian American Survey (NAAS) was designed to rectify this shortcoming (Ramakrishnan et al. 2018). The only nationally representative survey of the U.S. Asian population that includes 10 Asian ethnic groups and is offered in 10 Asian languages, the 2016 NAAS focuses on the social, political, and economic attitudes and experiences of Asians, including their views of affirmative action. The survey also includes sizeable samples of whites, blacks, and Hispanics, thereby making interracial comparisons possible.

Based on analyses of the 2016 NAAS, we study Asians' attitudes on affirmative action in four parts. First, we examine whether Asians support racial preferences in the hiring and promotion of blacks and gauge their attitudes vis-à-vis those of whites and blacks - who have historically evinced the most polarized positions-as well as to Hispanics. Because Asians experience labor market disadvantage yet are excluded from affirmative action programs, Asians may be even less likely than whites to support policies designed to give preferences to blacks.

Second, we build on Sniderman and Piazza's (1993) "mere mention" experimentin which they documented how the mere mention of affirmative action engenders negative attitudes of blacks-and examine whether the "mere mention of Asians" affects attitudes of affirmative action. Embedded in the 2016 NAAS is a three-way framing experiment in which we take advantage of the power of randomization to compare respondents' attitudes of affirmative action when Asians are introduced into the policy. The first affirmative action frame does not mention Asians and, therefore, serves as our control condition. The second frame mentions Asians as victims of affirmative action alongside whites, and the third mentions Asians as victims of discrimination alongside blacks. If support shifts across the frames, the reason must necessarily be that the mere mention of Asians and their group position in the frames encourages or discourages support for affirmative action because respondents were randomly assigned to one of three affirmative action frames. 
Third, we identify the social and psychological mechanisms that undergird support for each affirmative action frame. We consider how self-interest, group interest, beliefs about equality, and immigrant generation influence support for a policy that is often perceived as a zero-sum game in which group membership is privileged over meritocratic ideals (Norton and Sommers 2011). The tension between group membership and beliefs about meritocracy has become increasingly complex because affirmative action has evolved beyond the black-white binary to reflect America's new racial diversity.

Fourth, we examine whether differences emerge by immigrant generation among the Asian respondents. That four out of five Asian adults are immigrants is a unique feature of the U.S. Asian population (Lee, Ramakrishnan, and Wong 2018), which may mask significant differences by generational status in Asians' support for affirmative action. Hence, we disaggregate Asians by immigrant status and assess whether differences emerge between foreign-born and U.S.-born Asians, and we further disaggregate U.S.-born Asians into second- and third-and-higher-generation Asians.

By placing Asians at the center of our analyses, we document- for the first timewhether Asians are more likely to perceive themselves and be perceived by others as victims of affirmative action whose experiences align more closely with whites or as victims of discrimination whose experiences align more closely with blacks. Furthermore, by documenting how U.S. racial groups respond to the mere mention of Asians in affirmative action frames, the study unveils the malleability of opinion of a policy that is facing an unprecedented challenge. Finally, by disaggregating Asians by immigrant generation, we show significant differences in a group that is often perceived and studied as a monolith and touted by pundits as ardent critics of affirmative action.

\section{Affirmative Action and America's New Racial Diversity}

\section{Asians' Attitudes Toward Affirmative Action}

White and black Americans have consistently held the most polarized views of affirmative action, with the former being significantly less likely to support the policy than the latter (Moberg et al. forthcoming). Whether Asians resemble whites or blacks in their attitudes is a timely social and political question about which there has been scant research, apart from two descriptive reports (Ramakrishnan and Wong 2018; Wong et al. 2018). The first report focuses exclusively on Asian registered voters and shows that the majority are more likely to support rather than oppose "affirmative action programs designed to help blacks, women, and other minorities gain access to better jobs and education" (Ramakrishnan and Wong 2018).

In the second report, Wong et al. (2018) focus on affirmative action in university admissions and show that how the policy is framed affects Asians' opinions. Asians are more likely to support policies designed to create greater access to higher education for blacks, women, and other minorities than they are to support policies designed to increase their numbers on university campuses. This is consistent 
with prior research that shows that affirmative action policies designed to increase access garner more support because they connote the commitment to equality of opportunity for all Americans regardless of race or gender. By contrast, policies intended to increase the number of individuals from disadvantaged and underrepresented groups generate more opposition because they invoke the notion of quotas, which Americans equate with predetermining outcomes and, therefore, deem unmeritocratic (Kinder and Sanders 1990; Sniderman and Carmines 1997).

Although both reports provide the first descriptive accounts of Asians' attitudes of affirmative action, neither test the malleability of opinion when Asians are included into affirmative action frames, nor do they delve into the social or psychological drivers that undergird opinion. In addition, neither focus specifically on Asians' views of affirmative action in the workplace-a domain that has become increasingly consequential for U.S.-born, second-generation Asians as they transition from education to work and lose their educational advantage (Alba and Barbosa 2016; Tran et al. 2019).

Finally, neither report examines intergenerational differences in attitudes despite the robust literature that has documented the significance of immigrant generation in influencing policy attitudes, civic engagement, and socioeconomic integration (Jiménez 2009; Kasinitz et al. 2008; Lee and Bean 2010; Lee and Zhou 2015; Portes and Rumbaut 2001; Tran 2018; Tran et al. 2018). Whether U.S.-born Asians will be more or less likely to support preferences for blacks in the workplace is not straightforward. On the one hand, most Asian immigrants hail from countries that lack race-based affirmative action policies. Consequently, they may be less familiar with and less likely to support group-based preferences than their U.S.born counterparts. In addition, Asian immigrants hold more conservative social and political attitudes compared with U.S.-born Asians (Ramakrishnan et al. 2018).

On the other hand, because U.S.-born Asians are more likely to be employed in racially diverse, professional organizations compared with their foreign-born counterparts, the former are more directly affected by workplace affirmative action policies. As a result, U.S.-born Asians may be more likely to oppose polices that give preferences in the hiring and promotion of blacks, who they may perceive as potential threats to their prospects for occupational advancement. Hence, secondand later-generation Asians may respond by suppressing their support for affirmative action, especially in a frame that mentions Asians as aggrieved victims alongside whites.

Yet it is also possible that U.S.-born Asians may be more supportive of workplace preferences for blacks because they have a more sophisticated understanding of the origins and legacy of black disadvantage than their Asian immigrant counterparts. Thus, U.S.-born Asians-and especially third-and-higher-generation Asians-may be more likely to support affirmative action policies to address black-white inequality and most likely to support the policy as it was historically designed and intended. 


\section{The Group Position and Group Threat of Asians}

Opposition to affirmative action is, in part, a response to group threat. Research has shown that whites perceive increasing racial progress and diversity as threats to their dominant group position, leading them to respond in ways that maintain their status and position in the U.S. racial hierarchy (Blumer 1958; Bobo and Hutchings 1996). For example, the mere mention that the United States will become a "majorityminority" society has led whites—regardless of political affiliation-to endorse more conservative policy positions on issues like immigration and oppose equityenhancing policies like affirmative action (Craig and Richeson 2014; Danbold and Huo 2015; Jardina 2019; Mutz 2018; Wilkins and Kaiser 2014).

Although this body of scholarship has documented how whites respond to the threat of the growth of minority populations, we note two empirical shortcomings. First, researchers often invoke the growth of minority groups as representing an aggregated, single source of threat to whites without considering the possibility that different minority groups may pose distinct types of threat. Despite their rapid growth at 6.7 percent of the total U.S. population, Asians do not pose the demographic threat of Hispanics, the latter presently accounting for 18 percent of the U.S. population and having surpassed blacks as the largest minority group in the United States since 2000.

Rather, Asians pose an economic threat stemming from their immigrant hyperselectivity and socioeconomic attainment as well as a cultural threat due to their perceived foreignness (Jiménez and Horowitz 2013; Kim 1999; Lee and Zhou 2015; Tran et al. 2018, 2019; Xu and Lee 2013; Zou and Cheryan 2017). By illustration, the visible presence of Asians in elite universities has led whites to favor policies that would suppress the admission of Asians and also boost the admission of whites (Samson 2013). Whites decrease the importance of grade point averages when they are primed about Asian university applicants yet increase their significance when primed about black applicants. Hence, whites do not have a fixed stance on the importance of grade point averages for college admissions; rather, their construction of "merit" shifts in attempts to secure their group position and status (Alon and Tienda 2007; Karabel 2006). How whites respond to the mere mention of Asians in affirmative action has never been tested.

Second, the focus on the response among whites has obfuscated how minority groups respond to the threat of other minority groups. For example, when primed about the growth of the Hispanic population, black and white Americans respond by choosing the most privileged identity to which they can lay claim and that which also excludes Hispanics as one of "us" (Abascal 2015). Whites identify more strongly with their racial identity as white, whereas blacks identify more strongly with their national identity as American. Hence, the mere mention of Hispanics' population growth, in and of itself, affects whites' and blacks' choice of identification differently yet in ways that maintain their dominant group position over Hispanics.

In a parallel vein, whites and blacks may respond to the mere mention of Asians in affirmative action frames in distinct ways that also privilege their group position. When Asians are mentioned as aggrieved victims alongside whites, whites may increase their opposition and depress their support for affirmative action. Under the same condition, however, blacks may increase their support because they are 
primed that two more advantaged groups are poised against them. Opinions may also shift when Asians are mentioned as aggrieved minorities alongside blacks, with whites increasing their opposition when they are primed about two minority groups positioned against them. Indeed, the mere mention of Asians may shift support for affirmative action among all groups-including Asians-in ways that reflect responses to perceived group threat and attempts to safeguard group interests and position.

\section{Social and Psychological Drivers of Support for Affirmative Action}

Attitudes about affirmative action are not only a response to group threat but are also rooted in beliefs about merit, equality, and equal opportunity (Kluegel and Smith 1983). Some Americans believe that the United States is a meritocracy and, by extension, endorse the belief that individuals should be rewarded on the basis of talent, effort, and performance regardless of group membership (Sniderman and Piazza 1993; Son Hing, Bobocel, and Zanna 2002). Embedded in the meritocratic ideal is the assumption that access to opportunity is equal among all individuals and groups and that, consequently, inequality is the product of cultural or moral deficiencies (Bobo and Charles 2009). Americans who endorse this individualistic view of inequality henceforth believe that government should not play an active role in remedying group-based inequalities, including supporting and enforcing policies like affirmative action.

Others adopt a structural view of inequality and thus believe that group-based inequalities reflect historic de jure and de facto discriminatory institutional policies and practices that continue to place some groups at a structural advantage over others (Bobo, Kluegel, and Smith 1997). The belief that group-based inequalities are structural in origin-rather than a result of individual cultural or moral deficiencies—often leads to greater support for legal and institutional policy interventions, such as affirmative action, to address the inequality of opportunity (Bobo and Kluegel 1993).

Whites and blacks remain deeply divided in their views of racial inequality, with whites being significantly more likely than blacks to attribute black disadvantage to individualistic explanations such as a lack of motivation; blacks, by contrast, are more likely to endorse structural explanations such as racial discrimination (Hunt 2007). That whites are more likely to believe that racial inequality can be reduced to individualistic explanations explains, in part, why they are more likely to oppose affirmative action than blacks.

Not only do beliefs about and commitment to equality drive support for affirmative action but so do perceptions about the "moral deservingness" of the intended beneficiary. Whites are more likely to oppose preferences for blacks than they are to oppose preferences for women, veterans, and European Americans; moreover, they are most likely to oppose affirmative action policies that designate blacks as the sole beneficiaries (Fox 2012; Katznelson 2005; Skrentny 1996, 2006; Sniderman and Piazza 1993). That support for affirmative action varies depending on the intended beneficiary-and plummets when blacks are the lone beneficiaries-underscores that the principle of group-based preferences, in itself, does not dictate whites' opin- 
ion of affirmative action (Skrentny 1996). Rather, whites draw distinctions among disadvantaged and underrepresented groups and favor preferences for those they deem as morally deserving (Ridgeway forthcoming).

Attitudes about affirmative action are also driven by self-interest. Those who believe the policy will expand their access to scarce material or immaterial resources are more likely to support it, which explains, in part, why blacks and women are more likely to support affirmative action than whites and men (Crosby, Iyer, and Sincharoen 2006; Harrison et al. 2006). Self-interest can operate in two distinct, but not mutually exclusive, ways in the labor market. First, those who directly benefit from affirmative action are more likely to support it. Second, those who report having experienced discrimination may be more likely to support the policy because they may perceive the need for systematic, legal measures like affirmative action to address it.

Group interest can also drive support for affirmative action, independent of selfinterest, and sometimes even in spite of it through the strength of linked fate and racial identity. Linked fate embodies the belief among black Americans that their life chances are inextricably linked to the success and advancement of their racial group (Dawson 1995). Operating as a heuristic about what is in their best interest, it drives blacks to prioritize the well-being of their racial group even when it may at times conflict with their own self-interest. The strength of linked fate among blacks is most evident in their voting behavior, their support for the Democratic Party, and their unified views on progressive policies like affirmative action (Hochschild and Weaver 2015).

Although the strength of linked fate boosts blacks' support for affirmative action, the strength of racial identity has the opposite effect for whites. The more strongly whites identify with their racial group, the more likely they are to oppose affirmative action when whites believe they will incur losses as a result of the policy (Jardina 2019; Lowery et al. 2006). Whites' concern for the in-group increases opposition for affirmative action policies that are framed as zero-sum games and threaten their group position (Norton and Sommers 2011). Absent from the literature is how self-interest, group interest, beliefs about equality, and immigrant generation may affect support for affirmative action among Asians, especially when they are introduced into the policy. Also missing from previous research is how the mere mention of Asians in affirmative action frames may shift support among other U.S. racial groups such that groups that strongly support the policy under one condition are less willing to do so in another.

\section{Data and Methods}

\section{The 2016 National Asian American Survey}

The analyses are based on the 2016 National Asian American Survey-a telephone survey conducted between November 10, 2016, and March 2, 2017, that includes 4,393 adult respondents who report their ancestry or at least one parent's ancestry from countries in Asia. About two-thirds of the telephone interviews (63 percent) were conducted via landline, and the other 37 percent was conducted via cell phone. 
Whereas prior surveys of the U.S. Asian population focused on a few large Asian groups and were conducted in English only, the 2016 NAAS includes sizeable subsamples of 10 Asian groups: Chinese (475), Indian (504), Filipino (505), Korean (499), Vietnamese (501), Japanese (517), Pakistani (320), Bangladeshi (320), Hmong (351), and Cambodian (401). ${ }^{2}$ The survey also includes four non-Asian groups: Hispanics (1,126), non-Hispanic whites (408), non-Hispanic blacks (401), and Native Hawaiians and Pacific Islanders (NHPIs) (120)—-thereby allowing us to assess the levels and drivers of support for affirmative action for both Asian and non-Asian groups. $^{3}$

Moreover, in addition to English and Spanish, the 2016 NAAS was offered in 10 Asian languages: Mandarin, Cantonese, Korean, Vietnamese, Hindi, Tagalog, Japanese, Hmong, Cambodian, and Laotian. This is critical for data validity because 74 percent of U.S. Asian adults speak a language other than English at home, and 35 percent are limited in English language proficiency, which means that they speak English "less than very well" and speak a non-English language at home (U.S. Census Bureau 2016). Providing the option to complete the survey in a native language generates a more reliable sample of the U.S. Asian population because it avoids biasing the sample toward English-proficient, U.S.-born, highly educated, and younger Asians (Lee and Pérez 2014).

The 2016 NAAS was conducted by Catalist, a data and survey research firm that specializes in sampling smaller racial and ethnic groups, such as Asians, using a propriety sampling procedure referred to as the Catalist Ethnicity Model. Catalist has developed a suite of national models that predict the relative likelihood of membership in an Asian ethnicity, such as Chinese or Vietnamese, as opposed to the racial category of Asian or Pacific Islander. The full details of the Catalist Ethnicity Model appear in Appendix B of the online supplement. With this model, the 2016 NAAS achieved a response rate of 28 percent despite the challenges of surveying minority populations that have been well-documented in the research methods literature (Kalton and Anderson 1986).

Moreover, the 2016 NAAS is weighted to reflect the 2016 American Community Survey (ACS) population distribution in the following demographic characteristics: gender, age, state of residence, nativity, educational attainment, and citizenship status. For example, the proportion of foreign-born Asian respondents in the NAAS sample (78.6 percent) is nearly identical to the proportion in the ACS sample (79 percent). The proportions of Asians with more than a high school degree (71 percent) and of female Asians respondents (54 percent) are identical in both the 2016 NAAS and ACS samples.

\section{The Mere Mention of Asians in Affirmative Action Frames}

We rely on the power of randomization to determine whether the mere mention of Asians in affirmative action frames can, in and of itself, affect support for or opposition to preferences for hiring and promotion of blacks in the workplace. The 2016 NAAS randomly assigns respondents into three experimental conditions, with each respondent being exposed to one of three affirmative action frames: Frame 1 does not mention Asians and, therefore, serves as the control condition; Frame 
2 mentions Asians as aggrieved victims alongside whites; and Frame 3 mentions Asians as aggrieved minorities alongside blacks.

Frame 1 draws on a standard question from the General Social Survey and reflects the original design and intent of affirmative action as a restorative justice policy that addresses past discrimination against blacks and the resultant inequality between blacks and whites. It presents an argument for the preferential hiring and promotion of blacks but also notes that this policy might discriminate against whites. Because it does not mention Asians, Frame 1 captures the baseline level of support for the policy among Asians, whites, blacks, and Hispanics. Frames 2 and 3 mention Asians but place them in different group positions as victims of affirmative action alongside whites or victims of discrimination alongside blacks, respectively. Table 1 presents the question wording for the three frames, in which we highlight the variation.

Although respondents were randomly assigned to one of three experimental conditions, all respondents were asked the same question about their opinion on affirmative action: "Are you for or against preferential hiring and promotion of blacks?" We ask the same question of all respondents for four reasons. First, holding the question constant enables us to document how the mere mention of Asians and their changing group position affects preferences for blacks in the workplace. Second, by focusing on a single minority group as the intended beneficiary-and specifically the racial group for whom affirmative action was originally designed and intended-we can accurately assess how the mere mention of Asians affects support for preferences for blacks. Third, because whites are the least likely to support affirmative action when blacks are the lone beneficiary of the policy, focusing solely on blacks as the beneficiary provides a robust empirical test of whether the mere mention of Asians can shift support for racial preferences. Fourth, the question on workplace preferences for blacks has been pretested and asked by the General Social Survey biennially since 1984, reflecting its reliability.

\section{Dependent Variable}

The dependent variable measures respondents' support for racial preferences for blacks using the responses to the above question from all respondents across three affirmative action frames. This categorical variable encompasses three responses and is coded as follows: (-1) oppose, (0) no opinion, and (1) support. Rather than treating "no opinion" as a residual category or excluding it from our analyses, we treat it as a discrete category for two reasons. First, some foreign-born Asians and Hispanics may be unfamiliar with affirmative action policies that give preferences for disadvantaged or underrepresented groups, especially because most hail from countries that lack such policies. Second, no opinion may reflect ambivalence about giving preferential treatment to blacks in the workplace, which may shift once Asians are mentioned in the affirmative action frames. Although we include no opinion as a discrete category, we focus the multivariate analyses on the differences between support and opposition in the main text. 
Table 1: Three-way framing experiment of preferential hiring and promotion. Source: 2016 National Asian American Survey.

\section{Frame 1: Asians not mentioned in frame (i.e., control condition)}

Some people say that because of past discrimination, blacks should be given preference in hiring and promotion. Others say that such preference in hiring and promotion of blacks is wrong because it discriminates against whites. What about your opinion-are you for or against preferential hiring and promotion of blacks?

\section{Frame 2: Asians as aggrieved victims alongside whites}

Some people say that because of past discrimination, blacks should be given preference in hiring and promotion. Others say that such preference in hiring and promotion of blacks is wrong because it discriminates against groups like whites and Asian Americans. What about your opinion-are you for or against preferential hiring and promotion of blacks?

\section{Frame 3: Asians as aggrieved minorities alongside blacks}

Some people say that because of past discrimination, groups like blacks and Asian Americans should be given preference in hiring and promotion. Others say that such preference in hiring and promotion of groups like blacks and Asian Americans is wrong because it discriminates against whites. What about your opinion-are you for or against preferential hiring and promotion of blacks?

\section{Independent Variables}

The key independent variables are race and affirmative action frame. For our multivariate analyses, we include four sets of independent variables that predict attitudes toward affirmative action: demographic characteristics, self-interest, group interest, and support for federal equity-enhancing policies. The descriptive statistics for all variables by race for whites, blacks, Asians, Hispanics, and NHPIs are in Table A1 in Appendix A in the online supplement. In the main text, we focus on results for the four largest U.S. groups: whites, blacks, Hispanics, and Asians. Although Native Hawaiian and Pacific Islanders are in our analyses, we do not discuss them in the article given their small sample size (120).

First, we adjust for respondents' demographic characteristics-age, gender, political party identification, and socioeconomic status (i.e., education, income, and home ownership) — which have been shown to influence attitudes on affirmative action (see Crosby et al. [2006] for a full review). Apart from the standard demographic variables, we add other control variables that are germane to the U.S. Asian population: immigrant generation, relationship status, and state of residence.

Immigrant generation is a categorical variable, indicating whether a respondent is first, second, or third-and-higher generation. We rely on respondents' place of birth and their parents' countries of birth to determine the generational status for all racial groups. The first generation includes foreign-born respondents $(4,031)$. The second generation includes those born in the United States who reported two foreign-born parents (852) or at least one foreign-born parent (278). The third-andhigher generation includes those born in the United States with two U.S.-born parents $(1,287)$. Asians and Hispanics are more likely than whites and blacks to be first or second generation. 
The geographic variable is a dummy indicating whether the respondent lives in California, which we include for three reasons. First, California boasts the highest concentration of Asians in the United States at 14 percent-more than double the national average. Second, one-third of the 2016 NAAS Asian respondents lived in California at the time of survey. Third, Proposition 209 (also known as the California Civil Rights Initiative) went into effect in 1996, making California the first of only eight states with a ban on affirmative action as of 2019. Specifically, Proposition 209 prohibits state-level governmental institutions from considering race, ethnicity, or gender in public employment and public contracting.

Second, we adjust for self-interest using two survey measures. The first is a dichotomous variable asking whether the respondent, a close relative, or a close personal friend has ever "successfully benefited from a job offer or a government contract" due to affirmative action. The second measure of self-interest captures respondents' experiences with discrimination. Here, we use a standardized index that combines six individual survey questions in which the respondents were asked if they have been treated poorly or unfairly by others in promotion, hiring, firing, housing search, neighborhoods, and the police, with higher values indicating higher numbers of experiences with discrimination. The Cronbach's alpha for this index is 0.7. All details on the construction of this index are available in Appendix $C$ of the online supplement.

Third, we adjust for group interest using two survey measures: strength of linked fate and strength of racial identity. Strength of linked fate is an ordinal variable on a four-point scale that captures how much respondents think that "what happens to others of the same race in this country will affect what happens in their own life," ranging from "not at all" (0) to "a lot" (3). Strength of racial identity is an ordinal variable on a four-point scale that asks how important respondents' racial identity is to them, ranging from "not at all" (0) to "extremely important" (3).

Fourth, we measure respondents' beliefs in equality by gauging their support for equity-enhancing policies. Here, we also use a standardized index that combines six individual survey questions that ask respondents if they support federal government policies that reduce social inequality by lowering income inequality, increasing bank regulations, raising the minimum wage, increasing the income tax for the wealthy, encouraging corporate hiring of U.S.-born workers, and reducing student debt. Before constructing this index, we recoded the survey questions such that a higher value is associated with stronger commitment to equity policies. The Cronbach's alpha for this index is 0.7. All details on the construction of this index are available in Appendix $C$ of the online supplement.

\section{Modeling Strategies}

We approach our modeling strategies in three parts, relying on bivariate and multivariate results. First, we focus on racial differences in support for affirmative action by experimental frame. For the bivariate analyses of support by race and by frame, the three-way experimental design provides the opportunity to test for mean differences in support and opposition among respondents from each racial group who have been exposed to the three experimental frames. 
Second, because the dependent variable is categorical, we estimate multinomial logistic regressions with robust standard errors and report the relative risk ratios for all the coefficients.

For the multivariate analyses, we estimate three nested models for the same dependent variable separately for each framing condition. The first model controls only for race to establish baseline differences. The second includes other observable covariates for demographic characteristics and immigrant generation. The third further includes self-interest, group interest, and commitment to equality to examine how social and psychological drivers affect support for each frame.

By design, our multinomial logistic regressions estimate two distinct sets of coefficients. The first set compares those who support affirmative action with those who oppose it, whereas the second set compares those who report no opinion of the policy with those who oppose it. We choose oppose as our baseline category because we are interested in identifying the mechanisms that undergird support for affirmative action. Because of space constraints, we focus only on the contrast between support and oppose responses in the main text.

Third, we examine how immigrant generation may affect attitudes on affirmative action in the workplace among Asian respondents only. We focus specifically on Asian respondents for two reasons. First, Asians are the only U.S. racial group whose adult population is majority foreign born, accounting for 78.6 percent of Asians in the 2016 NAAS. By contrast, the overwhelming majority of blacks (89.6 percent) and whites (96.1 percent) in the survey are U.S. born, as are more than half of the Hispanics surveyed (50.6 percent). Second, the Asian sample in the 2016 NAAS is large enough to disaggregate Asians by immigrant generation and produce reliable estimates: 78.6 percent are first generation, 17.4 percent are second generation, and 4 percent are third-and-higher generation. We run the same multinomial logistic regressions for each of the three affirmative action frames, controlling for the full set of covariates described above. For all analyses, we adjust for the stratified survey design using appropriate final weights from the 2016 NAAS.

\section{Findings}

\section{Support for and Opposition to Affirmative Action by Race and Frame}

We begin by presenting the level of support for, no opinion on, and opposition to preferential hiring and promotion of blacks by race and frame in Figure 1. In Frame 1-in which Asians are not mentioned-blacks and whites represent the most polarized views: 61.5 percent of blacks support the policy, whereas 66.9 percent of whites oppose it. Asians align closely with whites in the control frame, with more than twice as many opposing the policy (57.5 percent) than supporting it (27.8 percent). Like whites and Asians, Hispanics evince greater opposition than support (46.6 percent versus 33 percent). They are also the most likely to express no opinion of the policy, with more than one-fifth of Hispanics choosing this option compared with only 6.1 percent of whites. Thus, despite the unique dilemma that Asians face with respect to affirmative action in the workplace, whites-not Asians-are the least likely to support racial preferences for blacks. 

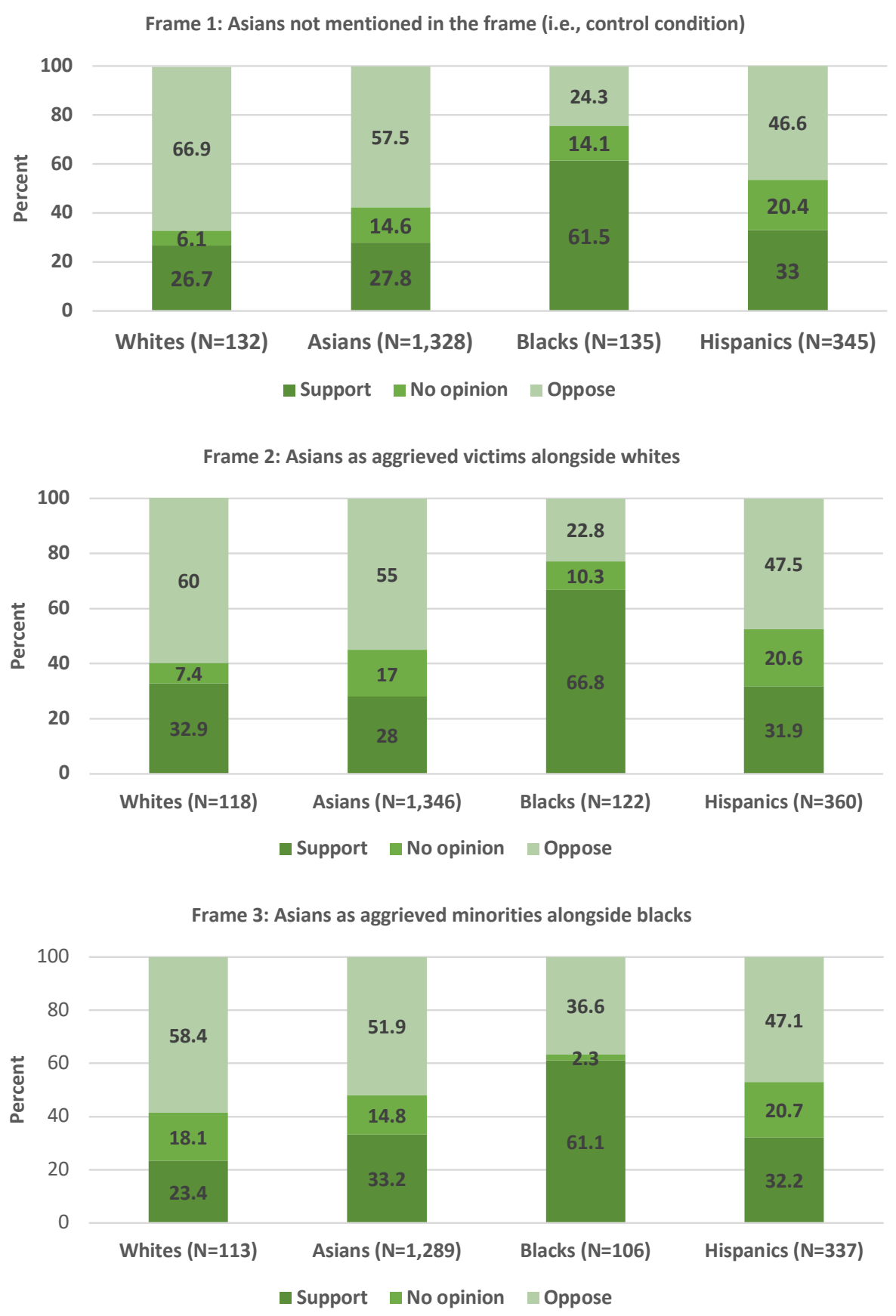

Figure 1: Attitudes on preferential hiring and promotion by frame and race. All figures are weighted percentages. Source: 2016 National Asian American Survey. 
In Frame 2-in which Asians are mentioned as aggrieved victims of the policy alongside whites-whites and blacks report a slight increase in support and a slight decrease in opposition compared with the control condition in Frame 1. Asians, however, do not significantly shift their support in Frame 2 compared with the control condition, suggesting that even when Asians are not mentioned as aggrieved victims of affirmative action, they perceive that they are.

In Frame 3-in which Asians are mentioned as aggrieved minorities alongside blacks-Asians' level of support is at its highest among the three frames, with one-third supporting the policy. This shift indicates that Asians' support of racial preferences for blacks is not only malleable but actually increases when they are primed about their past experiences with discrimination.

Whites and blacks also shift their support in Frame 3 but in the opposite direction of Asians. Whites' support decreases slightly and is lowest among the three frames when Asians are mentioned alongside blacks as aggrieved minorities, suggesting that whites respond to a heightened sense of group threat when two nonwhite minority groups are poised against them. The slight decrease in support among whites, however, pales in comparison to the stark increase in opposition among blacks, more than one-third (36.6 percent) of whom express opposition to the policy when Asians are mentioned as aggrieved minorities alongside them. The majority of the shift among blacks comes from those who once expressed no opinion of the policy who now oppose it. Finally, Hispanic opinion remains stable across the three affirmative action frames, most likely because they are not mentioned in any.

In the next set of analyses, we move beyond descriptive statistics and capitalize on the experimental design of the 2016 NAAS. Given our interest in the effect of framing on support for preferences in the hiring and promotion of blacks, we systematically test for significant differences in the mean level of support by race in Frames 2 and 3 by comparing each to the control condition in Frame 1. Given the coding of the categorical dependent variable, the baseline value of zero reflects neither support nor opposition (i.e., no opinion). Positive mean values reflect support, whereas negative mean values indicate opposition to the preferential hiring and promotion of blacks.

Although Figure 1 focuses on the proportions of support or opposition, Figure 2 focuses on differences in the mean level of support using two-tailed $t$ tests on the difference in means across the three affirmative action frames. The full statistics on the mean difference tests in Figure 2-including the relevant $t$ statistics and $p$ values-appear in Table A2 in Appendix A of the online supplement.

In Figure 2, blacks' attitudes significantly depart from all other groups. Their mean level of support for affirmative action is not only positive but is strongly positive in all three frames. In fact, there are no statistically significant differences in support among blacks across the three affirmative action frames, indicating that the mere mention of Asians and their shifting group position do not significantly affect blacks' mean level of support for the policy.

Although blacks evince the strongest mean level of support irrespective of the affirmative action frame, whites evince the strongest mean level of opposition irrespective of frame. The divergence in attitudes between blacks and whites confirms prior research that shows that these two groups hold the most polarized positions 


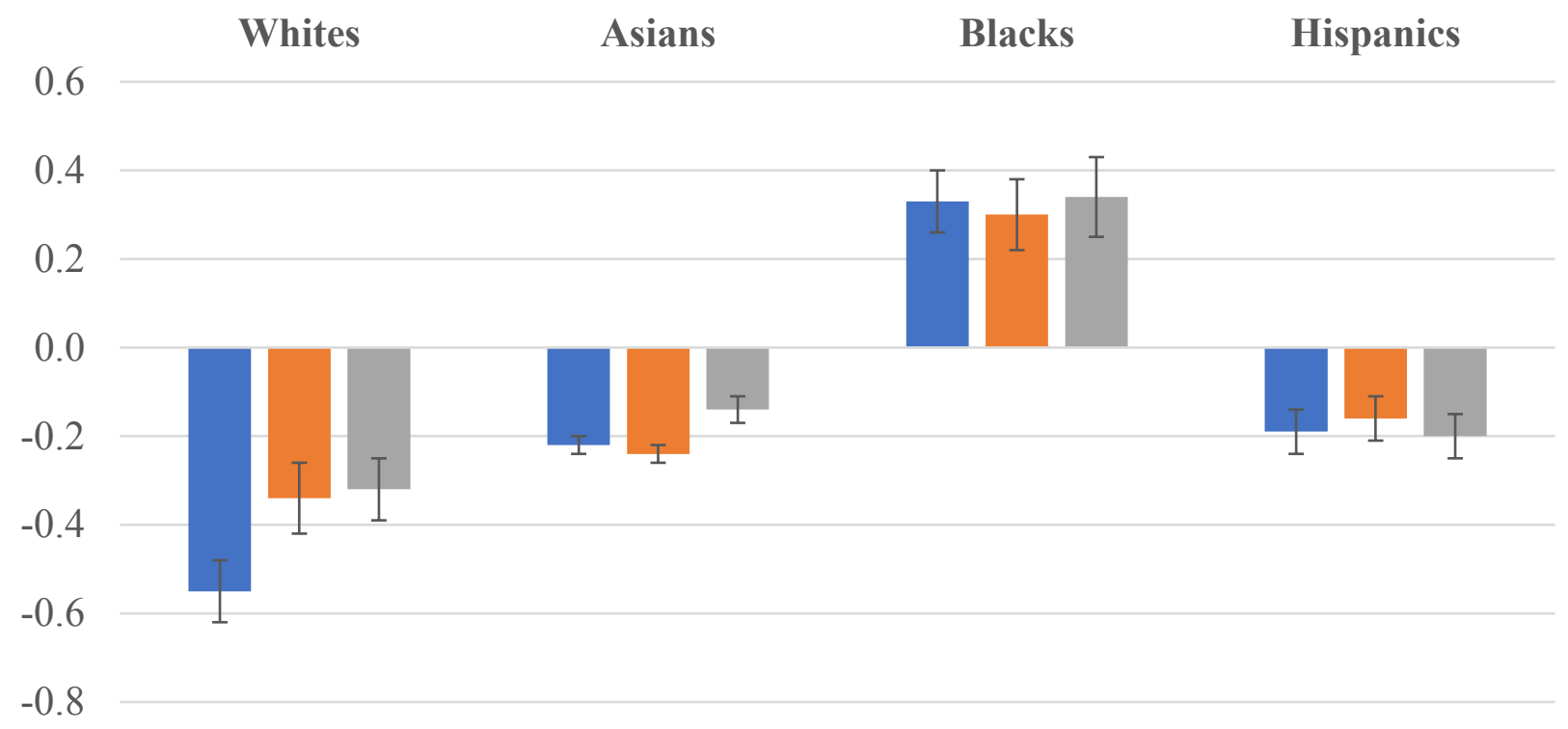

\section{- Frame 1: Asians not mentioned (i.e., control condition)}

\section{- Frame 2: Asians as aggrieved victims alongside whites}

\section{- Frame 3: Asians as aggrieved minorities alongside blacks}

Figure 2: Differences in mean support for preferential hiring and promotion by frame and race. Whiskers are standard errors. Full details on t tests and $\mathrm{p}$ values are included in Table A2 of the online supplement. Source: 2016 National Asian American Survey.

on affirmative action. In Frame 1, whites' level of opposition is highest (-0.545) when Asians are not mentioned. When Asians are mentioned in the affirmative action frames as either aggrieved victims alongside whites in Frame 2 or as aggrieved minorities alongside blacks in Frame 3, opposition among whites decreases by about 40 percent compared with the baseline level in Frame 1. Although the difference in means among whites between Frames 1 and 2 is sizeable, it does not reach statistical significance. The difference in means between Frames 1 and 3, however, is statistically significant at the $p<.05$ level. Whites are significantly less likely to oppose racial preferences for blacks when primed about the past discrimination against both Asians and blacks and when Asians are positioned alongside blacks as aggrieved minorities.

Among Asians, their mean level of opposition is higher than their mean level of support across the three affirmative action frames, yet their opposition is lower than that of whites in each. Furthermore, like whites, the difference in means between Frames 1 and 2 is not statistically significant, but it is significant between Frames 1 and 3. That Asians' and whites' attitudes shift in the same direction between Frames 1 and 3 indicates that the mere mention of Asians as a disadvantaged racial group significantly reduces their opposition to racial preferences for blacks.

Like whites and Asians, Hispanics, on average, are more likely to oppose rather than support the policy irrespective of the frame. In Frames 1 and 2, Hispanic 
Table 2: Selected variables from multinomial logistic regressions on preference for hiring and promotion by frame: support versus oppose. Source: 2016 National Asian American Survey.

\begin{tabular}{|c|c|c|c|c|c|c|c|c|c|}
\hline & \multicolumn{3}{|c|}{$\begin{array}{l}\text { Asians not mentioned } \\
\text { (i.e., control) }\end{array}$} & \multicolumn{3}{|c|}{$\begin{array}{c}\text { Asians as } \\
\text { aggrieved victims }\end{array}$} & \multicolumn{3}{|c|}{$\begin{array}{c}\text { Asians as } \\
\text { aggrieved minorities }\end{array}$} \\
\hline & $(1)$ & $(2)$ & (3) & (4) & (5) & (6) & (7) & $(8)$ & (9) \\
\hline Asian versus white & $\begin{array}{l}1.215 \\
(0.465)\end{array}$ & $\begin{array}{c}2.092 \\
(0.988)\end{array}$ & $\begin{array}{l}1.881 \\
(1.027)\end{array}$ & $\begin{array}{c}0.930 \\
(0.288)\end{array}$ & $\begin{array}{l}1.734 \\
(0.779)\end{array}$ & $\begin{array}{c}0.862 \\
(0.441)\end{array}$ & $\begin{array}{l}1.598 \\
(0.443)\end{array}$ & $\begin{array}{r}3.000^{*} \\
(1.537)\end{array}$ & $\begin{array}{c}1.492 \\
(0.802)\end{array}$ \\
\hline Black versus white & $\begin{array}{r}6.348^{\dagger} \\
(2.930)\end{array}$ & $\begin{array}{r}8.969^{\dagger} \\
(3.708)\end{array}$ & $\begin{array}{r}3.914^{\dagger} \\
(1.985)\end{array}$ & $\begin{array}{r}5.340^{+} \\
(2.211)\end{array}$ & $\begin{array}{r}4.795^{\dagger} \\
(2.287)\end{array}$ & $\begin{array}{c}2.269 \\
(1.267)\end{array}$ & $\begin{array}{r}4.174^{+} \\
(1.698)\end{array}$ & $\begin{array}{r}4.292^{+} \\
(1.971)\end{array}$ & $\begin{array}{l}1.629 \\
(0.798)\end{array}$ \\
\hline Hispanic versus white & $\begin{array}{l}1.779 \\
(0.730)\end{array}$ & $\begin{array}{r}2.644^{*} \\
(1.180)\end{array}$ & $\begin{array}{c}2.163 \\
(1.169)\end{array}$ & $\begin{array}{l}1.229 \\
(0.414)\end{array}$ & $\begin{array}{l}1.137 \\
(0.505)\end{array}$ & $\begin{array}{c}0.494 \\
(0.275)\end{array}$ & $\begin{array}{c}1.712 \\
(0.528)\end{array}$ & $\begin{array}{l}2.060 \\
(1.016)\end{array}$ & $\begin{array}{c}0.870 \\
(0.490)\end{array}$ \\
\hline $\begin{array}{l}\text { Native Hawaiian/Pacific } \\
\text { Islander versus white }\end{array}$ & $\begin{array}{l}3.792^{*} \\
(2.318)\end{array}$ & $\begin{array}{r}6.769^{+} \\
(4.640)\end{array}$ & $\begin{array}{c}5.404 \\
(5.768)\end{array}$ & $\begin{array}{c}0.465 \\
(0.297)\end{array}$ & $\begin{array}{c}0.573 \\
(0.466)\end{array}$ & $\begin{array}{c}0.274 \\
(0.252)\end{array}$ & $\begin{array}{l}0.956 \\
(0.481)\end{array}$ & $\begin{array}{l}1.202 \\
(0.683)\end{array}$ & $\begin{array}{c}0.754 \\
(0.459)\end{array}$ \\
\hline $\begin{array}{l}\text { Second versus } \\
\text { first generation }\end{array}$ & & $\begin{array}{c}2.592 \\
(1.261)\end{array}$ & $\begin{array}{r}2.812^{*} \\
(1.459)\end{array}$ & & $\begin{array}{c}0.700 \\
(0.363)\end{array}$ & $\begin{array}{c}0.950 \\
(0.502)\end{array}$ & & $\begin{array}{l}1.877 \\
(0.980)\end{array}$ & $\begin{array}{c}1.951 \\
(1.026)\end{array}$ \\
\hline $\begin{array}{l}\text { Third-and-higher versus } \\
\text { first oeneration }\end{array}$ & & $\begin{array}{c}1.741 \\
(0.884)\end{array}$ & $\begin{array}{c}2.111 \\
(1.146)\end{array}$ & & $\begin{array}{l}1.568 \\
(0.738)\end{array}$ & 2.396 & & 2.176 & $\begin{array}{c}2.131 \\
(1.183)\end{array}$ \\
\hline $\begin{array}{l}\text { first generation } \\
\text { Benefited from affirmative } \\
\text { action policy }\end{array}$ & & $(0.884)$ & $\begin{array}{r}(1.146) \\
3.244^{+} \\
(1.244)\end{array}$ & & $(0.738)$ & $\begin{array}{l}(1.211) \\
1.403 \\
(0.884)\end{array}$ & & (1.190) & $\begin{array}{r}(1.183) \\
6.510^{+} \\
(2.968)\end{array}$ \\
\hline Discrimination index & & & $\begin{array}{l}1.221 \\
(0.186)\end{array}$ & & & $\begin{array}{r}0.682^{*} \\
(0.110)\end{array}$ & & & $\begin{array}{c}0.959 \\
(0.201)\end{array}$ \\
\hline Racial linked fate & & & $\begin{array}{l}1.106 \\
(0.164)\end{array}$ & & & $\begin{array}{l}1.201 \\
(0.221)\end{array}$ & & & $\begin{array}{l}1.128 \\
(0.160)\end{array}$ \\
\hline Strength of racial identity & & & $\begin{array}{c}0.866 \\
(0.166)\end{array}$ & & & $\begin{array}{l}1.348 \\
(0.259)\end{array}$ & & & $\begin{array}{l}1.253 \\
(0.225)\end{array}$ \\
\hline Equity-enhancing policies & & & $\begin{array}{r}2.557^{+} \\
(0.608)\end{array}$ & & & $\begin{array}{r}2.244^{+} \\
(0.606)\end{array}$ & & & $\begin{array}{l}1.867^{*} \\
(0.529)\end{array}$ \\
\hline Demographic controls & No & Yes & Yes & No & Yes & Yes & No & Yes & Yes \\
\hline $\mathrm{N}$ & 1,976 & 1,976 & 1,976 & 1,985 & 1,985 & 1,985 & 1,902 & 1,902 & 1,902 \\
\hline
\end{tabular}

Notes: All coefficients are relative risk ratios. Robust standard errors are in parentheses. Full results are shown in Table A3 of the online supplement. ${ }^{*} p<0.05,{ }^{+} p<0.01$

opposition is lower than that of Asians, but in Frame 3, Hispanics' is higher. Despite their higher opposition in Frame 3, there are no significant differences in mean levels across the three affirmative action frames for Hispanics, indicating that the mere mention of Asians does not have a significant impact on their attitudes about racial preferences for blacks.

\section{Social and Psychological Drivers of Support for Affirmative Action Frames}

Because significant differences are limited to only whites and Asians in the above analyses, we now turn to multivariate analyses by frame, focusing on the social and psychological drivers of support for each affirmative action frame. Here, we use whites as the reference group because they exhibit the lowest level of support and highest level of opposition across all three frames.

Table 2 presents results from multinomial logistic regressions, highlighting the support-versus-oppose comparison. We present only the selected variables from the nested models in Table 2, focusing on those that are most relevant: race, immigrant generation, and social and psychological drivers of support. However, we discuss other significant findings from the full results when relevant. (The full set of results are in Tables A3 and A4 in Appendix A of the online supplement.) 
In Frame 1, the control condition that does not mention Asians, model 1 shows that blacks report higher relative risk ratios of support for the policy compared with whites by a factor of 6.3. Adjusting for demographic characteristics in model 2 , blacks' support is still significantly higher than that of whites by a factor of 8.9, and Hispanic support is higher than that of whites by a factor of 2.6. That blacks and Hispanics are more likely to express support for preferences in the hiring and promotion of blacks compared with whites is consistent with prior research (Crosby et al. 2006). Controlling for self-interest and group interest in model 3 , support for the policy among blacks remains significantly higher than it does among whites by a factor of 3.9. Although the relative risk ratios of support for the policy are also higher among Asians and Hispanics than among whites in model 3, these differences are not significant, indicating that blacks are exceptional in their high level of support for affirmative action when the policy is framed in a black-white binary.

In model 3, second-generation respondents report higher relative risk ratios of support compared with the first-generation respondents by a factor of 2.8. This generational difference, however, disappears in both Frames 2 and 3 when Asians are mentioned as aggrieved victims and aggrieved minorities, respectively. That support is significantly higher among second-generation respondents compared with first-generation respondents only in Frame 1 indicates that the former are more likely to support the historical design and intent of an affirmative action policy that specifically addresses inequality between blacks and whites as a result of past discrimination against blacks.

Among other covariates, self-interest and commitment to equality boost support: those who benefited from affirmative action and those who support equityenhancing policies both report higher relative risk ratios by factors of about three. However, neither experiences with discrimination nor group interest (i.e., linked fate and racial identity) affect support for the policy.

In Frame 2, in which Asians are mentioned as aggrieved victims alongside whites, models 4 and 5 show that blacks continue to evince significantly higher levels of support compared with whites by a factor of about five after adjusting for all demographic covariates. However, blacks' support for the policy drops in significance altogether in model 6. After adjusting for self-interest and group interest, blacks are no more likely than whites to support in-group preferences in hiring and promotion with the mere mention of Asians as aggrieved victims alongside whites.

Commitment to equality remains one of the strongest predictors of support in Frame 2. However, respondents who benefited from affirmative action are no more likely to support racial preferences in the hiring and promotion of blacks when Asians are mentioned as aggrieved victims. In addition, the association between experiences of discrimination and support for affirmative action is negative: those who reported having experienced higher levels of discrimination are significantly less likely to support affirmative action.

Education also emerges a significant predictor in models 5 and 6 (Table A3 in the online supplement), but its effect is in the opposite direction as found in prior research (Crosby et al. 2006). Although college-educated Americans are generally 
more likely to support racial preferences for disadvantaged and underrepresented groups, our results show that college graduates are significantly less likely to support the preferential hiring and promotion of blacks with the mere mention of Asians as aggrieved victims alongside whites. The relative risk ratios of policy support for the education coefficient decrease by a factor of 0.3 in models 5 and 6. These findings suggest that positioning Asians as aggrieved victims elevates the sense of group threat among college-educated respondents and those who have experienced discrimination, resulting in the withdrawal of their support for affirmative action for blacks in the workplace.

In Frame 3, in which Asians are mentioned as aggrieved minorities alongside blacks, both models 7 and 8 show that blacks report higher relative risk ratios of support compared with whites by a factor of four. Adjusting for demographic covariates, model 8 shows that Asians report higher relative risk ratios of support compared with whites by a factor of three. In only this model, the difference between Asians and whites is significant, indicating that Asians' support is higher than whites' when they are primed about their past experiences with discrimination and positioned alongside blacks as aggrieved minorities against whites.

In model 9, adjusting for other covariates, the Asian and black coefficients drop in significance, revealing that their support is no longer significantly higher than that of whites. In this model, support among women decreases, with the relative risk ratio for females only half that of males, indicating that females respond to the mere mention of Asians as a disadvantaged group by dampening their support (see Table A3 in the online supplement). The decrease in support among women may point to their dissatisfaction with a policy frame that includes two nonwhite minority groups as aggrieved minorities yet excludes women-an underrepresented group that has historically been included in workplace affirmative action policies. Like Frame 1, those who benefited from affirmative action evince significantly higher levels of support in Frame 3, with the relative risk ratio reaching close to 6.5. Moreover, respondents who support equity-enhancing policies report increased support by a factor of nearly two.

To underscore, the most notable finding in these models is that blacks' support of affirmative action is conditional on the exclusion of Asians. Regardless of whether Asians are positioned as aggrieved victims or as aggrieved minorities, the mere mention of Asians in affirmative action significantly depresses blacks' support of the policy to such a degree that is no longer distinguishable from that of whites. Put differently, black support for in-group preferences in the workplace is significantly higher than that of whites only when blacks are mentioned as the sole aggrieved minority and whites the sole aggrieved victim of the policy. That the magnitude of the relative risk ratios for the black coefficients is largest in Frame 1-compared with Frames 2 and 3-provides further evidence that blacks' support for affirmative action is conditional on the exclusion of Asians.

We offer two interpretations of this finding. First, the mere mention of Asians might activate a sense of group threat among blacks regardless of how Asians are positioned in the frames. This may reflect blacks' awareness of Asians' high socioeconomic status. Consequently, a survey framing manipulation that positions Asians as aggrieved minorities may not be powerful enough to dislodge blacks' 
Table 3: Selected variables from multinomial logistic regressions on preference for hiring and promotion by frame, Asian respondents only. Source: 2016 National Asian American Survey.

\begin{tabular}{|c|c|c|c|c|c|c|}
\hline & \multicolumn{2}{|c|}{$\begin{array}{l}\text { Asians not mentioned } \\
\text { (i.e., control) }\end{array}$} & \multicolumn{2}{|c|}{$\begin{array}{c}\text { Asians as } \\
\text { aggrieved victims }\end{array}$} & \multicolumn{2}{|c|}{$\begin{array}{c}\text { Asians as } \\
\text { aggrieved minorities }\end{array}$} \\
\hline & (1) & (2) & (3) & (4) & (5) & (6) \\
\hline & $\begin{array}{c}\text { Support } \\
\text { versus } \\
\text { oppose }\end{array}$ & $\begin{array}{c}\text { No } \\
\text { opinion } \\
\text { versus } \\
\text { oppose }\end{array}$ & $\begin{array}{c}\text { Support } \\
\text { versus } \\
\text { oppose }\end{array}$ & $\begin{array}{c}\text { No } \\
\text { opinion } \\
\text { versus } \\
\text { oppose }\end{array}$ & $\begin{array}{c}\text { Support } \\
\text { versus } \\
\text { oppose }\end{array}$ & $\begin{array}{c}\text { No } \\
\text { opinion } \\
\text { versus } \\
\text { oppose }\end{array}$ \\
\hline Second versus first generation & $\begin{array}{c}1.659 \\
(0.498)\end{array}$ & $\begin{array}{c}1.644 \\
(0.643)\end{array}$ & $\begin{array}{l}1.197 \\
(0.369)\end{array}$ & $\begin{array}{l}1.514 \\
(0.524)\end{array}$ & $\begin{aligned} 2.039^{*} \\
(0.697)\end{aligned}$ & $\begin{array}{c}1.422 \\
(0.733)\end{array}$ \\
\hline $\begin{array}{l}\text { Third-and-higher versus } \\
\text { first generation }\end{array}$ & $\begin{array}{r}2.912^{+} \\
(0.870)\end{array}$ & $\begin{array}{l}2.297 \\
(1.084)\end{array}$ & $\begin{array}{l}2.261 \\
(1.069)\end{array}$ & $\begin{array}{l}0.799 \\
(0.407)\end{array}$ & $\begin{array}{l}1.793 \\
(0.587)\end{array}$ & $\begin{array}{c}0.864 \\
(0.441)\end{array}$ \\
\hline $\begin{array}{l}\text { Benefited from affirmative } \\
\text { action policy }\end{array}$ & $\begin{array}{c}3.054^{+} \\
(0.976)\end{array}$ & $\begin{array}{l}2.229 \\
(0.987)\end{array}$ & $\begin{array}{l}1.676 \\
(0.499)\end{array}$ & $\begin{array}{c}0.997 \\
(0.448)\end{array}$ & $\begin{array}{l}0.643 \\
(0.220)\end{array}$ & $\begin{array}{c}0.430 \\
(0.263)\end{array}$ \\
\hline Discrimination index & $\begin{array}{l}1.114 \\
(0.115)\end{array}$ & $\begin{array}{c}0.845 \\
(0.120)\end{array}$ & $\begin{array}{l}1.330^{*} \\
(0.163)\end{array}$ & $\begin{array}{l}1.046 \\
(0.179)\end{array}$ & $\begin{array}{r}1.427^{\dagger} \\
(0.173)\end{array}$ & $\begin{array}{c}1.339 \\
(0.223)\end{array}$ \\
\hline Racial linked fate & $\begin{array}{l}1.124 \\
(0.097)\end{array}$ & $\begin{array}{l}0.990 \\
(0.110)\end{array}$ & $\begin{array}{l}1.172 \\
(0.105)\end{array}$ & $\begin{array}{r}0.779^{*} \\
(0.089)\end{array}$ & $\begin{array}{l}1.123 \\
(0.099)\end{array}$ & $\begin{array}{c}0.857 \\
(0.102)\end{array}$ \\
\hline Strength of racial identity & $\begin{array}{r}1.277^{*} \\
(0.138)\end{array}$ & $\begin{array}{l}1.071 \\
(0.125)\end{array}$ & $\begin{array}{l}1.195 \\
(0.131)\end{array}$ & $\begin{array}{l}1.033 \\
(0.130)\end{array}$ & $\begin{array}{l}1.241^{*} \\
(0.133)\end{array}$ & $\begin{array}{c}0.970 \\
(0.112)\end{array}$ \\
\hline Equity-enhancing policies & $\begin{array}{r}1.458^{\dagger} \\
(0.186)\end{array}$ & $\begin{array}{l}1.122 \\
(0.137)\end{array}$ & $\begin{array}{r}1.559^{+} \\
(0.191)\end{array}$ & $\begin{array}{c}1.108 \\
(0.154)\end{array}$ & $\begin{array}{r}1.730^{+} \\
(0.213)\end{array}$ & $\begin{array}{l}1.046 \\
(0.148)\end{array}$ \\
\hline Constant & $\begin{array}{c}1.057 \\
(0.770)\end{array}$ & $\begin{array}{r}0.243^{*} \\
(0.175)\end{array}$ & $\begin{array}{c}1.358 \\
(0.983)\end{array}$ & $\begin{array}{r}0.097^{+} \\
(0.086)\end{array}$ & $\begin{array}{c}0.428 \\
(0.291)\end{array}$ & $\begin{array}{r}0.056^{+} \\
(0.044)\end{array}$ \\
\hline Log pseudolikelihood & $-873,895$ & $-873,895$ & $-886,028$ & $-886,028$ & $-905,022$ & $-905,022$ \\
\hline Demographic controls & Yes & Yes & Yes & Yes & Yes & Yes \\
\hline $\mathrm{N}$ & 1,328 & 1,328 & 1,346 & 1,346 & 1,289 & 1,289 \\
\hline
\end{tabular}

Note: All coefficients are relative risk ratios. Robust standard errors are in parentheses. Full results are available upon request. ${ }^{*} p<0.05,{ }^{\dagger} p<0.01$

perceptions of Asians. Second, it may reflect blacks' steadfast commitment to support the origin of affirmative action as a policy designed to rectify the past discrimination against blacks by whites, one in which blacks are the sole aggrieved minority and intended beneficiary vis-à-vis whites.

\section{Support for Affirmative Action Among Asians by Immigrant Generation}

In the third set of analyses, we focus exclusively on Asian respondents and assess how immigrant generation influences their views of affirmative action in the workplace. We estimate multinomial logistic regressions on the three affirmative action frames, controlling for the full set of covariates in Table A1, except race. The results for selected coefficients from these models appear in Table 3, but the full set results are available upon request from the authors. 
In Frame 1-which does not mention Asians—support is lowest among firstgeneration Asians. It is significantly lower among first-generation Asians compared to the third-and-higher-generation Asians, with the latter evincing a relative risk ratio of 2.9 in support of the policy. Although second-generation Asians also evince stronger support than the first generation, the difference does not reach statistical significance (see model 1, Table 3).

Differences in support between first- and second-generation Asians do reach statistical significance, however, in Frame 3. When Asians are included in the frame and positioned as aggrieved minorities alongside blacks, the relative risk ratio of support is twice that of second-generation Asians as the first generation (see model 5, Table 3). Second-generation Asians respond more favorably in an affirmative action frame that primes them about their past experiences with discrimination and places them as aggrieved minorities alongside blacks.

In Frame 2-when Asians are mentioned as aggrieved victims alongside whitesthere are no significant differences by immigrant generation, pointing to Asians' more unified policy views when Asians are mentioned as aggrieved victims of affirmative action alongside whites. In addition, among third-and-higher-generation Asians, the relative risk ratios for support are virtually identical in Frames 2 and 3, indicating that shifting the group position of Asians in affirmative action frames does not affect their opinion of racial preferences for blacks. As the most assimilated Asian group, third-and-higher-generation Asians may be the most aware of the historical origins of the policy as well as Asians' socioeconomic status vis-à-vis blacks and whites. Consequently, they are the least likely to shift their support for the hiring and promotion of blacks based on the changing group position of Asians in affirmative action frames. ${ }^{4}$

\section{Discussion and Conclusions}

The battle over affirmative action has been ongoing for decades, but for the first time in U.S. history, Asians have taken center stage. Allegations of bias against Asian college applicants have captivated the nation in the latest assault against affirmative action and placed affirmative action on trial, whereas reports of bias against Asians in the workplace have raised few eyebrows. Presumed competent, Asians evince exceptional educational outcomes, yet many lack the cultural pedigree of elite whites that safeguard them from bias in the labor market (Khan 2011; Lee and Zhou 2015; Rivera 2012). In spite of their nonwhite minority status, Asians also lack the legacy of disadvantage of blacks that would make them eligible beneficiaries of affirmative action in the workplace. This places Asians in a unique bind: do they support policies that give preferences to minority groups like blacks but exclude them? This bind should make Asians unlikely to do so and, in fact, should make them even less likely than whites to support race-based preferences.

\section{Shifting Frames and Shifting Support}

Our analyses reveal that in spite of the bind, whites-rather than Asians-remain the most opposed to and least supportive of racial preferences for blacks in the 
workplace. Regardless of whether the policy is framed within a black-white binary, whether Asians are mentioned as aggrieved victims alongside whites, or whether Asians are mentioned as aggrieved minorities alongside blacks, whites hold the most entrenched negative views of affirmative action and evince the strongest opposition across the three frames.

Although whites are the most opposed and least supportive of race-based preferences for blacks, Asians align closely with them, especially when Asians are mentioned alongside blacks as aggrieved minorities. In this frame, both Asians' and whites' mean level of opposition for affirmative action drops significantly, indicating that their opposition to affirmative action not only is malleable but also weakens when they are primed about the history of discrimination against both blacks and Asians. In sum, the mere mention of Asians as aggrieved minorities assuages opposition among the two most socioeconomically advantaged U.S. racial groups.

Blacks also evince malleable attitudes in their support of affirmative action. Although blacks express the strongest support of all groups and across all frames, their support is highest and their opposition is lowest when Asians are not mentioned at all, indicating that they are most likely to endorse the affirmative action frame that reflects the historical intent of the policy. Blacks' support shifts significantly when Asians are mentioned in the frames and plummets to the level of whites' support, revealing just how significantly the mere mention of Asians in affirmative action depresses blacks' support for the policy. Although Hispanics express attitudes that typically fall in between those of whites and blacks, they are the most likely to express no opinion of the policy irrespective of the frame, even after adjusting for covariates, thus possibly reflecting their exclusion from all three frames.

That the mere mention of Asians as aggrieved minorities decreases the mean level of opposition to affirmative action among whites and Asians yet depresses support among blacks underscores the importance of studying attitudes about affirmative action in the context of America's new racial diversity. Support shifts in different directions with the mere mention of Asians for whites and Asians on the one hand and blacks on the other, pointing to a pattern of "black exceptionalism" in attitudes toward affirmative action.

\section{Social and Psychological Drivers of Support}

Self-interest and beliefs about equality are the two main drivers of support for affirmative action: respondents who benefited from the policy and those who favor equity-enhancing federal policies are significantly more likely to endorse preferential hiring and promotion for blacks. Although we include these two variables in our multivariate analyses based on prior research that underscores their significance in predicting attitudes of affirmative action, we are aware that adjusting for these two attitudinal measures while simultaneously predicting attitudes towards affirmative action can be interpreted as potentially problematic. In our sensitivity analyses, we estimate additional models that adjusted for the full set of covariates except for these two key measures. The findings are virtually identical to those reported in models 3, 6, and 9 in Tables A3 and A4 in Appendix A in the online 
supplement. (These results are not included here but are available from the authors upon request.)

For Frame 1, blacks are more likely to express support than whites by a factor of 7.6 without adjusting for these two variables (model 3 in Table A3 in the online supplement), whereas this coefficient drops to 3.9 when including these two variables. This confirms our prior conclusion that self-interest (i.e., having benefited from the policy) and a stronger preference for equity-enhancing policies are key drivers behind blacks' exceptionally high level of support for the policy. In Frames 2 and 3 (models 6 and 9 in Table A3 in the online supplement), the relative risk ratios of supporting the policy for blacks remain both statistically insignificant and virtually unchanged in coefficient size, with or without the inclusion of these two variables. Similarly, the coefficients for Asians and Hispanics in the fully adjusted models do not differ substantially from models 3, 6, and 9 in Table A3 in the online supplement.

Although neither linked fate nor strength of racial identity are significant predictors of support, the discernible shifts in support across the three affirmative action frames among whites, Asians, and blacks reveal the salience of the group threat and group position of Asians. At the same time, these findings underscore that these two measures of group interest-initially developed to explain differences in the political attitudes and behavior of blacks and whites in the United States-are too coarse to capture the ways in which group interest operates in the context of America's new racial diversity. Looking ahead, social scientists should develop more sophisticated measures of group identity and group interest for nonwhite, nonblack, and immigrant populations.

\section{The False Equivalency of Nonwhite Disadvantage}

Our results also reveal that education is negatively associated with support of affirmative action at the mere mention of Asians as aggrieved victims alongside whites (Frame 2). In this frame, college graduates are the least likely to support preferences in the hiring and promotion of blacks. That support drops when two advantaged groups - whites and Asians-are included as aggrieved victims appears to heighten group threat among college-educated professionals, who respond by weakening their support for a policy that gives workplace preferences to blacks. Although more research is needed to explain this negative association between education and support for affirmative action, we offer a plausible explanation.

One reason the debate about affirmative action is so contentious stems from the "causation fallacy" - the common, yet mistaken, notion among opponents of affirmative action that when members of advantaged groups are denied admission to a university or passed over for a job or promotion in favor of minority candidates, the likely cause is affirmative action (Kang 1996; Liu 2002; Liu 2008). The causation fallacy has gained currency in the latest challenge to affirmative action, in which its opponents tout the inequity of a policy that privileges some racial minority groups like blacks and disadvantages others like Asians. Such claims are founded on the false equivalency of nonwhite disadvantage between Asians and blacks in the United States, which, in turn, provides specious support for the claim that 
Asians are both the victims of affirmative action and victims of discrimination who are unjustly penalized because of their race, whereas blacks are unjustly rewarded for theirs.

The false equivalency of nonwhite disadvantage fails to account for the historical, legal, and structural disadvantages that blacks continue to face in the United States, which have both cumulative and intergenerational consequences. As nonwhites, Asians have endured immigration restrictions, legal exclusion from U.S. citizenship, anti-Asian hostility, violence, discrimination, and even internment (Lee 2015; Lew-Williams 2018; Ngai 2004). But as nonblacks, Asians have escaped centuries of slavery, the legal codification of racial inferiority, and the intergenerational disadvantage that blacks have suffered as a result (Lee and Bean 2010; Wu 2015). Asians may be a disadvantaged minority relative to whites, but they are an advantaged minority relative to blacks (Kim 2018).

The false equivalency of nonwhite disadvantage has been lost in the latest challenge to affirmative action. In Students for Fair Admissions v. Harvard, the plaintiffs allege that Asian applicants need higher standardized test scores and grade point averages to be admitted to Harvard compared to racial minorities like blacks, who gain admission with significantly lower scores and grades. Altogether missing from this logic is a fundamental question: should we treat nonwhites as equally disadvantaged? Or, alternatively, are we willing to recognize the different kinds, degrees, and consequences of nonwhite disadvantage? Umbrella terms like "minority," "disadvantage," and "discrimination" elide these differences, thereby enabling critics of affirmative action to make a facile argument that Asians are the new victims of affirmative action.

The differences in support for affirmative action among Asians by generational status suggest that the most assimilated Asians recognize the false equivalency of nonwhite disadvantage. Third-and-higher-generation Asians express significantly weaker support when Asians are included in the affirmative action frames, indicating that they-like blacks-support the policy as it was initially designed and intended: to address and rectify the historical origins and resultant consequences of black-white inequality. That third-and-higher-generation Asians respond to the mere mention of Asians as aggrieved minorities by weakening their support suggests that the inclusion of Asians as victims of discrimination akin to blacks is at odds with their perception of where Asians fit in the U.S. racial hierarchy.

Second-generation Asians, by contrast, evince the significantly higher support when Asians are mentioned as aggrieved minorities alongside blacks. We provide two possible explanations for the divergent patterns between second-generation and the third-and-higher-generation Asians. First, as children of immigrants, secondgeneration Asians have grown up in immigrant households and, therefore, may be less attentive to and less sympathetic of the ways in which race-and specifically blackness-continues to affect the life chances of blacks in the workplace compared to their third-and-higher-generation Asian counterparts. Second, because secondgeneration Asians are entering the professional labor market, they are confronting new forms of institutional bias (Huang 2019). Consequently, they may be more likely to perceive themselves as aggrieved victims of discrimination who should be-but are not-included in race-based affirmative action programs in the workplace. 
The group that evinces the weakest support for affirmative action among Asians is the first generation. Not only do they hail from countries that lack race-based affirmative action policies, but because of language and cultural barriers, many highly educated and hyperselected Asian immigrants are unable to transfer their premigration education, skills, and capital into the U.S. labor market (Lee 2002). Although Asian immigrants experience labor market disadvantage, they do not qualify for affirmative action programs in the workplace. Hence, some feel that they are both victims of discrimination and victims of affirmative action and believe that the policy is a direct attack on their interests and the interests of their children (Xiaoqing 2019).

Because Asian immigrant adults outnumber their U.S.-born counterparts by 4 to 1 , their experiences and attitudes have taken precedence in the current debate about affirmative action (Lee and Ramakrishnan forthcoming). Data disaggregation by immigrant generation, however, unveils the heterogeneity in opinion among Asians that is masked when studying Asians as a monolith. Although affirmative action is facing an unprecedented challenge in the context of America's new racial diversity, the most assimilated Asians agree that Asians and blacks do not share the same disadvantaged group position and thus should not be poised alongside each other in an affirmative action policy as though they do.

\section{Notes}

1 We use the term Asians to refer to Asian Americans throughout the article and do not make distinctions among Asian ethnic groups because the aim of this article is to compare intergroup attitudes among Asians, whites, blacks, and Hispanics.

2 Although the 2016 NAAS provides sufficient sample sizes to examine intra-Asian diversity, the focus of our article is on interracial differences in support.

3 Of the 6,448 respondents in the 2016 NAAS, 36 self-identified as mixed race. We classified 31 as Asian and 5 as NHPIs because they indicated some Asian ethnic heritage or NHPI heritage. Our findings are not sensitive to the inclusion or exclusion of these 36 mixed-race respondents.

4 There are no significant differences by immigrant generation among Asians between those with no opinion and those who oppose the policy (models 2, 4, and 6 in Table 3).

\section{References}

Abascal, Maria. 2015. "Us and Them: Black-White Relations in the Wake of Hispanic Population Growth." American Sociological Review 80:789-813. https://doi.org/10. $1177 / 0003122415587313$.

Alba, Richard, and Guillermo Y. Barbosa. 2016. "Room at the Top? Minority Mobility and the Transition to Demographic Diversity in the USA." Ethnic and Racial Studies 39:917-38. https://doi.org/10.1080/01419870.2015.1081966.

Alon, Sigal, and Marta Tienda. 2007. “Diversity, Opportunity, and the Shifting Meritocracy in Higher Education." American Sociological Review 72:487-511. https://doi.org/10. $1177 / 000312240707200401$. 
Blumer, Herbert. 1958. "Race Prejudice as a Sense of Group Position." Pacific Sociological Review 1:3-7. https://doi.org/10.2307/1388607.

Bobo, Lawrence D., and Camille Z. Charles. 2009. "Race in the American Mind: From the Moynihan Report to the Obama Candidacy." The ANNALS of the American Academy of Political and Social Science 621:243-59. https : //doi .org/10.1177/0002716208324759.

Bobo, Lawrence, and Vincent L. Hutchings. 1996. "Perceptions of Racial Group Competition: Extending Blumer's Theory of Group Position to a Multiracial Social Context." American Sociological Review 61:951-72. https: //doi .org/10.2307/2096302.

Bobo, Lawrence, and James R. Kluegel. 1993. “Opposition to Race-Targeting: Self-Interest, Stratification Ideology, or Racial Attitudes?" American Sociological Review 58:443-64. https://doi.org/10.2307/2096070.

Bobo, Lawrence, James R. Kluegel, and Ryan A. Smith. 1997. “Laissez-Faire Racism: The Crystallization of a Kinder, Gentler Anti-Black Ideology." Pp. 15-42 in Racial Attitudes in the 1990s, edited by S. A. Tuch and J. K. Martin. Greenwood, CT: Praeger.

Chung, Eric, Samuel Dong, Xiaonan A. Hu, Christine Kwon, and Goodwin Liu. 2017. “A Portrait of Asian Americans in the Law." Yale Law School and National Asian Pacific American Bar Association. https://www.apaportraitproject.org/.

Craig, Maureen A., and Jennifer A. Richeson. 2014. “On the Precipice of a 'Majority-Minority' America: Perceived Status Threat from the Racial Demographic Shift Affects White Americans' Political Ideology." Psychological Science 25:1189-97. https : //doi . org/10 . $1177 / 0956797614527113$.

Crosby, Faye J., Aarti Iyer, and Sirinda Sincharoen. 2006. "Understanding Affirmative Action." Annual Review of Psychology 57:585-611. https ://doi .org/10.1146/annurev .psych. 57 . 102904.190029.

Danbold, Felix, and Yuen J. Huo. 2015. “No Longer 'All-American'? Whites' Defensive Reactions to their Numerical Decline." Social Psychological and Personality Science 6:210-8. https://doi .org/10.1177/1948550614546355.

Dawson, Michael C. 1995. Behind the Mule. Princeton, NJ: Princeton University Press.

Fox, Cybelle. 2012. Three Worlds of Relief. Princeton, NJ: Princeton University Press.

Gee, Buck, and Denise Peck. 2017.2 "The Illusion of Asian Success." Ascend: Pan-Asian Leaders. https://cdn.ymaws.com/www.ascendleadership.org/resource/resmgr/research/TheIllusionofAsianSuccess.pdf.

Gee, Buck, Denise Peck, and Janet Wong. 2015. "Hidden in Plain Sight: Asian American Leaders in Silicon Valley." Ascend: Pan-Asian Leaders. https://cdn.ymaws.com/www.ascendleadership.org/resource/resmgr/research/hiddeninplainsight_paper_042.pdf.

Harrison, David A., David A. Kravitz, David M. Mayer, Lisa M. Leslie, and Dalit Lev-Arey. 2006. "Understanding Attitudes Toward Affirmative Action Programs in Employment: Summary and Meta-Analysis of 35 Years of Research." Journal of Applied Psychology 91:1013-36. https://doi.org/10.1037/0021-9010.91.5.1013.

Hochschild, Jennifer, and Vesla Weaver. 2015. "Is the Significance of Race Declining in the Political Arena? Yes, and No." Ethnic and Racial Studies 38:1250-7. https ://doi .org/10. 1080/01419870.2015.1016057.

Hsin, Amy, and Yu Xie. 2014. “Explaining Asian Americans' Academic Advantage Over Whites." Proceedings of the National Academy of Sciences 111:8416-21. https://doi .org/ 10.1073/pnas. 1406402111. 
Huang, Tiffany J. 2019. "Negotiating the Workplace: Second-Generation Asian American Professionals' Early Experiences." Unpublished manuscript.

Hunt, Matthew O. 2007. "African American, Hispanic, and White Beliefs about Black/White Inequality, 1977-2004." American Sociological Review 72:390-415. https://doi . org/10 . $1177 / 000312240707200304$.

Jardina, Ashley. 2019. White Identity Politics. New York, NY: Cambridge University Press.

Jiménez, Tomás R. 2009. Replenished Ethnicity. Berkeley, CA: University of California Press.

Jiménez, Tomás R., and Adam L. Horowitz. 2013. “When White Is Just Alright: How Immigrants Redefine Achievement and Reconfigure the Ethnoracial Hierarchy." American Sociological Review 78:849-71. https://doi .org/10.1177/0003122413497012.

Kalton, Graham, and Dallas W. Anderson. 1986. "Sampling Rare Populations." Journal of the Royal Statistical Society 149:65-82. https: //doi .org/10.2307/2981886.

Kang, Jerry. 1996. "Negative Action Against Asian Americans: The Internal Instability of Dworkin's Defense of Affirmative Action." Harvard Civil Rights-Civil Liberties Law Review 31:1-47.

Karabel, Jerome. 2006. The Chosen. New York, NY: Mariner Books.

Kasinitz, Philip, John H. Mollenkopf, Mary C. Waters, and Jennifer Holdaway. 2008. Inheriting the City. New York, NY: Russell Sage Foundation.

Katznelson, Ira. 2005. When Affirmative Action Was White. New York, NY: W.W. Norton \& Company.

Khan, Shamus. 2011. Privilege. Princeton, NJ: Princeton University Press.

Kim, Claire Jean. 1999. "The Racial Triangulation of Asian Americans." Politics E Society 27:105-38.

Kim, Claire Jean. 2018. “Are Asians the New Blacks?" Du Bois Review 15:217-44. https: //doi.org/10.1017/S1742058X18000243.

Kim, ChangHwan, and Arthur Sakamoto. 2010. "Have Asian American Men Achieved Labor Market Parity with White Men?" American Sociological Review 75:934-57. https : //doi.org/10.1177/0003122410388501.

Kim, ChangHwan, and Yang Zhao. 2014. "Are Asian American Women Advantaged? Labor Market Performance of College Educated Female Workers." Social Forces 93:623-52. https://doi.org/10.1093/sf/sou076.

Kinder, Donald R., and Lynn M. Sanders. 1990. "Mimicking Political Debate with Survey Questions: The Case of White Opinion on Affirmative Action for Blacks." Social Cognition 8:73-103. https://doi.org/10.1521/soco.1990.8.1.73.

Kluegel, James R., and Eliot R. Smith. 1983. "Affirmative Action Attitudes: Effects of Self-Interest, Racial Affect, and Stratification Beliefs on Whites' Views." Social Forces 61:797-824. https://doi .org/10.1093/sf/61.3.797.

Lee, Erika. 2015. The Making of Asian America. New York, NY: Simon \& Schuster.

Lee, Jennifer. 2002. "From Civil Relations to Racial Conflict." American Sociological Review 67:77-98.

Lee, Jennifer, and Frank D. Bean. 2010. The Diversity Paradox. New York, NY: Russell Sage Foundation.

Lee, Jennifer, and Karthick Ramakrishnan. Forthcoming. "Who Counts as Asian." Ethnic and Racial Studies. 
Lee, Jennifer, Karthick Ramakrishnan, and Janelle Wong. 2018. "Accurately Counting Asian Americans is a Civil Rights Issue." The ANNALS of the American Academy of Political and Social Science 667:191-202. https://doi .org/10.1177/0002716218765432.

Lee, Jennifer, and Min Zhou. 2015. The Asian American Achievement Paradox. New York, NY: Russell Sage Foundation.

Lee, Taeku, and Efrén O. Pérez. 2014. “The Persistent Connection Between Language-ofInterview and Hispanic Political Opinion." Political Behavior 36:401-25. https://doi . org/10.1007/s11109-013-9229-1.

Lew-Williams, Beth. 2018. The Chinese Must Go. Princeton, NJ: Princeton University Press.

Liu, Adrian. 2008. "Affirmative Action \& Negative Action: How Jian Li's Case Can Benefit Asian Americans." Michigan Journal of Race and Law 13:391-431.

Liu, Goodwin. 2002. "The Causation Fallacy: Bakke and the Basic Arithmetic of Selective Admissions." Michigan Law Review 100:1045-107. https: //doi . org/10 . 2307/1290503.

Lowery, Brian S., Miguel M. Unzueta, Eric D. Knowles, Phillip A. Goff. 2006. "Concern for the Ingroup and Opposition to Affirmative Action." Journal of Personality and Social Psychology 90:961-74. https://doi.org/10.1037/0022-3514.90.6.961.

Moberg, Sarah, Maria Krysan, and Deanna Christianson. Forthcoming. "Trends in Racial Attitudes." Public Opinion Quarterly.

Mutz, Diana C. 2018. "Status Threat, Not Economic Hardship, Explains the 2016 Presidential Vote." Proceedings of the National Academy of Sciences 115:E4330-9. https : //doi . org/10. 1073/pnas. 1718155115.

Ngai, Mae M. 2004. Impossible Subjects. Princeton, NJ: Princeton University Press.

Norton, Michael I., and Samuel R. Sommers. 2011. "Whites See Racism as a Zero-Sum Game That They Are Now Losing." Perspectives on Psychological Science 6:215-18. https : //doi.org/10.1177/1745691611406922.

Portes, Alejandro, and Rubén Rumbaut. 2001. Legacies: The Story of the Immigrant Second Generation. Berkeley, CA: University of California Press.

Ramakrishnan, Karthick, Jennifer Lee, Taeku Lee, and Janelle Wong. 2018. “National Asian American Survey (NAAS) 2016 Post-Election Survey." National Asian American Survey. http://naasurvey.com/data/.

Ramakrishnan, Karthick, and Janelle Wong. 2018. "Survey Roundup: Asian American Attitudes on Affirmative Action." AAPIData Data Bits. http://aapidata.com/blog/asianamaffirmative-action-surveys/.

Ridgeway, Cecilia L. Forthcoming. Status: Why Is It Everywhere? Why Does It Matter? New York, NY: Russell Sage Foundation.

Rivera, Lauren A. 2012. "Hiring as Cultural Matching: The Case of Elite Professional Service Firms." American Sociological Review 77:999-1022. https://doi .org/10.1177/ 0003122412463213.

Samson, Frank L. 2013. "Multiple Group Threat and Malleable White Attitudes Towards Academic Merit." Du Bois Review 10:233-60. https://doi.org/10.1017/ s1742058x1300012x.

Skrentny, John D. 1996. The Ironies of Affirmative Action. Chicago, IL: University of Chicago Press.

Skrentny, John D. 2006. "Policy-Elite Perceptions and Social Movement Success: Understanding Variations in Group Inclusion in Affirmative Action." American Journal of Sociology 111:1762-815. https://doi.org/10.1086/499910. 
Sniderman, Paul M., and Edward G. Carmines. 1997. Reaching Beyond Race. Cambridge, MA: Harvard University Press.

Sniderman, Paul M., and Thomas Piazza. 1993. The Scar of Race. Cambridge, MA: Harvard University Press.

Son Hing, Leanne S., D. Ramona Bobocel, and Mark P. Zanna. 2002. "Meritocracy and Opposition to Affirmative Action: Making Concessions in the Face of Discrimination." Journal of Personality and Social Psychology 83:493-509. https ://doi .org/10.1037//0022-3514. 83.3.493.

Tran, Van C. 2018. "Social Mobility Across Immigrant Generations: Recent Evidence and Future Data Requirements." The ANNALS of the American Academy of Political and Social Science 667:105-18. https://doi .org/10.1177/0002716218762725.

Tran, Van C., Jennifer Lee, and Tiffany J. Huang. 2019. "Revisiting the Asian SecondGeneration Advantage." Ethnic and Racial Studies 42:2248-69. https://doi.org/10. 1080/01419870.2019.1579920.

Tran, Van C., Jennifer Lee, Oshin Khachikian, and Jess Lee. 2018. "Hyper-Selectivity, Racial Mobility, and the Remaking of Race." The Russell Sage Foundation Journal of the Social Sciences 4:189-209. https://doi .org/10.7758/rsf.2018.4.5.09.

U.S. Census Bureau. 2016. “B02015. Asian Along by Selected Groups," 2016 American Community Survey 1-Year Estimates. https:// factfinder.census.gov/bkmk/table/1.0/en/ACS/16_1YR/B02015.

Wilkins, Clara L., and Cheryl R. Kaiser. 2014. "Racial Progress as Threat to the Status Hierarchy: Implications for Perceptions of Anti-White Bias." Psychological Science 25:43946. https://doi.org/10.1177/0956797613508412.

Wong, Janelle, Jennifer Lee, and Van C. Tran. 2018. “Asian Americans' Attitudes Toward Affirmative Action: Framing Matters." AAPIData Data Bits. http://aapidata.com/blog/aaattitudes-affirmative-action/.

$\mathrm{Wu}$, Ellen D. 2015. The Color of Success. Princeton, NJ: Princeton University Press.

Xiaoqing, Rong. 2019. "The Rise of the Chinese-American Right." National Review, July 17. Retrieved September 3, 2019, https:/ / www.nationalreview.com/2019/07/chineseamerican-right-new-generations-immigrants/.

Xu, Jun, and Jennifer C. Lee. 2013. “The Marginalized 'Model' Minority: An Empirical Examination of the Racial Triangulation of Asian Americans." Social Forces 91:1363-97. https://doi.org/10.1093/sf/sot049.

Zou, Linda X., and Sapna Cheryan. 2017. "Two Axes of Subordination: A New Model of Racial Position." Journal of Personality and Social Psychology 112:696-717. https://doi . org/10.1037/pspa0000080. 
Acknowledgments: Direct all correspondence to Jennifer Lee, Department of Sociology, Columbia University. E-mail: lee.jennifer@columbia.edu. This research was supported by grants from the National Science Foundation (1558986) and the Russell Sage Foundation (93-17-07). For comments and suggestions, we thank Maria Abascal, Aixa Cintrón-Vélez, Thomas DiPrete, Florencia Torche, Andreas Wimmer, and the editors of Sociological Science.

Jennifer Lee: Department of Sociology, Columbia University.

E-mail: lee.jennifer@columbia.edu.

Van C. Tran: Department of Sociology, The Graduate Center, CUNY.

E-mail: vtran@gc.cuny.edu. 